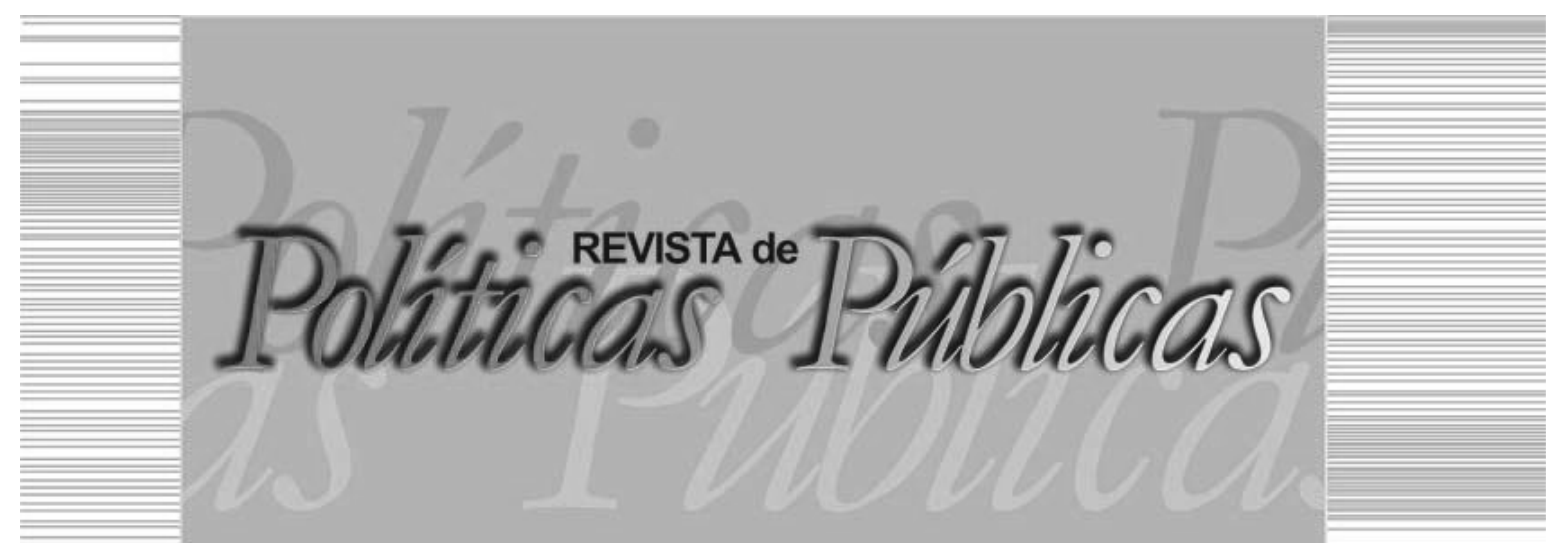

\title{
NO MORE OF THE SAME: the rise and fall of multiculturalism in Brazil
}

\section{Livio Sansone $e^{l}$}

\begin{abstract}
The category ethnic identity acquired popularity in the Eighties and Nineties, and since the late Nineties has made inroads in Brazil as well as in the rest of Latina America. The notion of multiculturalism followed the example, first in part of the Global North and little by little in our region as from the decade of 2000. Here I analyse the sudden rise of popularity of multiculturalism in Brazil and the rapid crisis it got into over the last few years, also on account of the rise of a new stock of an extreme right-wing populism.
\end{abstract}

Keywords: Identity, multiculturalism, cultural policies, inequalities.

NÃO MAIS DO MESMO: ascensão e queda do multiculturalismo no Brasil

\section{Resumo}

A categoria identidade étnica adquiriu popularidade nos anos 1980 e 1990, e desde o final desta última década ganhou espaço no Brasil, bem como no resto da América Latina. A noção de multiculturalismo seguiu o exemplo, primeiro em parte do Norte Global e pouco a pouco em nossa região a partir da década de 2000. Aqui analiso a ascensão repentina da popularidade do multiculturalismo no Brasil e a rápida crise que lhe abateu nos últimos anos, o que também

\footnotetext{
'Antropólogo, Doutor em Antropologia pela Universidade de Amsterdã, Holanda, Bolsista de Produtividade em Pesquisa do CNPq - Nível 1B, Coordenador do Programa Multidisciplinar de Pós-Graduação em Estudos Étnicos e Africanos da Universidade Federal da Bahia (UFBA). E-mail: liviosansone@yahoo.com / Endereço: Universidade Federal da Bahia - UFBA: Centro de Estudos Afro-Orientais - Largo Dois de Julho s/n, Centro, Salvador, BA - Brasil. CEP: 40225-010
} 
tem relação com o surgimento de um novo estoque de populismo de extrema direita.

Palavras-chave: Identidade, multiculturalismo, políticas culturais, desigualdades.

\section{INTRODUCTION}

I have been committed to ethnic studies since the beginning of my academic education, around 1976. Generally speaking one can say that over these decades ethnicity and even more so its positive side, diversity, has acquired a much more positive connotation in public policies related to culture and, up the end of the Nineties, ethnic minorities. Since then the question of integration has taken the lead in public policies and in the public space over the question of ethnic minority rights. Of course, since 9/11 the so-called excesses of multiculturalism have been highlighted, especially by right-wing politicians. Multiculturalism and its politics of recognition, as they have been understood since Charles Taylor-s classic (1994), started in the Global North and more specifically in a number of countries who choose to describe themselves as multicultural, as strategy towards establishing a new social contract with their ethnic or colonial minorities (Canada, Australia, Sweden, the Netherlands and, to a lesser extent, the UK and the USA). Over the last two or three decades multiculturalism has shoot roots also in several Asian and African countries, and all over Latin America. In many ways the social sciences have stayed relatively immune of the right wing turn against multiculturalism, which has been very violent in the Global North, but is also taking its toll in the Global South. Therefore, I maintain that time is ripe, in this period of rising populist exploration of ethnicity, diversity and its shadow side difference, for a critical appraisal of the mainstream neutral or moderately positive and, generally speaking, intellectually lazy attitude of social scientists towards notions such as multiculturalism, diversity and ethnic rights, as well as the use of these notions by public policies and the State. I will highlight this change of perspective, by which diversity is little by little re-signified from onus to bonus, in my own career as an anthropologist engaged with these issues and with public policy advice.

In 1992, upon completing my Phd, I was invited by the UN to contribute with an essay to the report Our Creative Diversity (PEREZ CUELLAR, 1996), compiled by the World Commission for 
Culture and Development. This commission, founded by United Nations Educational, Scientific and Cultural Organization (UNESCO) and the UN, started its work in 1993 under the leadership of former Secretary General Perez de Cuellar. The report stated that cultural differences should not only be tolerated, but that we should nurture them and learn from them, and that a society should welcome different groups of people, but fight ethnic and religious fanaticism (PEREZ CUELLAR, 1996). A number of junior and senior intellectuals were invited to comment. I was one of the (then) junior ones and the following was, in essence, my position, which was largely inspired by over a decade and a half research on ethnic minority formation in England and the Netherlands.

In a nutshell my point was that in order to appreciate the value of diversity you have to learn to relate to what is different. That means, for instance, not attaching cultural characteristics to a person's outward appearance or skin colour, but it also means addressing the traditional concept of ethnicity in a different way from that currently embraced by many academics. Ethnicity - whose dark side takes the form of racism and whose more generally accepted side is nationalism - had in recent years been an emotive subject in many countries and for many thinkers. Why is this?

It is not just bound up with the intellectual laziness of academics, but also with changing political agendas. When Marxism still had hegemony in many circles over political parlance, terms such as ethnicity were absolutely taboo. Modern antitheses had to be explained in terms of social classes. In the Nineties, however, Marxist and other related discourses on social progress and emancipation had given way to other, less structured collective dreams. They went hand-in-hand with new social conflicts which were less inspired by the principle of progress than by the idea of zero-sum-games - competition now only exists between various pressure groups; progress in one group is always at the cost of another, with the result that progress in the absolute sense could not exist.

The received view was that this process of secularization and individualization would soon result in the concept of ethnicity being relegated to the archaeology of social phenomena. The opposite, however, seemed to be the case. Modern thinkers talked about the quest for identity (BELL, 1980), the search for community (TURNER, 1983) and the birth of identity politics. In short, as a reaction 
to the loss of cultural individuality, ethnicity had, in fact, been given a new lease of life. And this in turn was the outcome of a series of interrelated factors which, for simplicity's sake, I shall here call globalization.

Globalization enables the worldwide dissemination of symbols which are associated with a number of local identities and individual characteristics. Symbols which suggest that it is worthwhile to be ethnically different (HANNERZ, 1992). This has the paradoxical consequence that, in terms of identity, these symbols lead to a marked heterogeneity, but in the cultural domain they create a stronger degree of homogeneity (VERMEULEN, 1994). For while this presents increasing opportunities to manifest oneself as 'different', the ways in which this is expressed are remarkably similar. As Wallerstein (1990) pointed out, it is not for nothing that most (new) forms of nationalism resemble one another, with rebel groups from Chechnia to the Ivory Coast and Mexico all dressing and behaving like local Rambos. This is because they have increasing recourse to the same symbol-bank - what Pieterse called global memory (1995) - which provides worldwide access to a combination of youth subcultures, musical styles and spectacular forms of nationalism. One can therefore speak of an ethnic identity without a separate, recognizable ethnic culture, whereby nowadays the separate black, Muslim and Indian identities can no longer be perceived independently of globalization.

Globalization and the attendant recognition of the value of ethnicity not only have an effect on immigrants and their descendants, particularly in Western or Western-orientated cities, they also precipitate changes in allochthones' societies. This is because autochthonous people come into contact with foreign cultures through direct or indirect contact and mass tourism, which bring about a massive change in the cultural landscape. In the Global North nowadays we have an enormous variety of restaurants; the consumption of world music is no longer the exclusive domain of intellectuals; and leisure facilities like discotheques, clubs and sports clubs also exhibit increasing ethnic diversity or have incorporated specific ethnic aspects. This in turn creates new boundaries and conditions for the development of ethnic identity and ethnically based survival strategies. All in all globalization produces both multicultural ideologies and new forms of racism. We appear to be moving towards new, less transparent and less romantic conflicts. Nevertheless, they 
are usually presented and interpreted under the simple blanket term: ethnicity.

It is not surprising that the media, which increasingly presents the world as an unbroken series of spectacular events, should play a decisive role in this. It is easier for a journalist or photographer to sell a story which takes ethnicity as its subject than one which addresses social differences. It is vital, however, to look further than the concept of ethnicity. Many conflicts, which at first sight appear to be of an ethnic nature (viz. Bosnia with the Muslims and the Serbs), on closer examination turn out to be much more complex social conflicts. Moreover, it is salutary to recognize that, fortunately, many people can live quite happily without such things as ethnicity. These people are mainly found in modern cities, where increasing numbers of inhabitants form part of more than one subculture, thereby creating a multi-layered social identity of which ethnicity is just one of many components. Even a Hutu is never simply just a Hutu.

Unfortunately, even in the language of the United Nation and UNESCO - usually in dossiers and reports that have to be succinct and at the same time moral, circumspect and diplomatic - one senses a tendency to associate culture with one (particular) ethnic and/or religious group. Culture is thus presented as virtually the equivalent of ethnicity. This approach perceives cultural production as a static whole, whereas, in fact, it is a perpetually changing process.

The social sciences also reflect this emphasis on ethnicity, in this instance the result of a general desire for sharp lines, for apollonian clarity. This naturally makes it easier to pigeonhole social phenomena into separate categories. The reality, however, is that the world is steadily becoming more ethnically and culturally intermingled, more Creole. But as yet academics are still bound by a narrow-mindedness that dismisses the elliptic, the Dionysian, syncretism and mestizoic as the cause and result of ambiguity, hypocrisy, even schizophrenia. Despite widespread confusion among academics the motto always remains: everything in its place, and a place for everything.

In the Netherlands - in common with many other countries the image of multi-culturalism was and still is strongly influenced by the thinking developed in the United States and other English-speaking countries like Australia and Canada. The typical North American vision of ethnicity and cultural diversity presupposes that ethnic 
distinctions are being increasingly sharply defined and immutably fixed - after all in the last two US censuses ethnic and racial identity is measured through the question "[...] which is your ethnicity?" (UNITED STATES CENSUS BUREAU, 2017). Creolization is seen as the result of white domination, ultimately leading to white supremacy.

Since in the years 1980-1992 I was based at the University of Amsterdam my perspective at the time was largely inspired by the way the Netherlands fared the waters of multiculturalism. However, although the Netherlands can certainly serve as an example on several scores, if only because this country's greatness is partly derived precisely from the respect that in various stages of its history has been accorded to dissidents and, to a lesser extent, to people who look different, it should not see itself as a model. Firstly, the Netherlands is an affluent, literally over-insured country, thereby occupying a decidedly unrepresentative position in the world. And secondly, the Netherlands also harbours taboos, as underscored by any infringement of freedom within a particular sociopolitical group. The golden particularism thus finds its obverse expression in education, particularly in the disturbing proliferation of the phenomenon of special schools for black people and people with learning difficulties (LOM). In discussing these matters with parents of autochthonous and educationally normal children, one comes to realize just how fundamental, ethnic and even egotistical the average Dutch person's thoughts and feelings can be when it comes down to protecting their individual freedom.

But is there such a thing as a model country, a country with ideal interethnic relations, a truly multicultural country? No, we must give up searching for existing paradigms and accept that there is no model country. The utopia of a country where ethnic origin forms only one of the many differences - no more nor less - can only be realized by the interactive combination of specific aspects of different types of interethnic relations. We must, as it were, create this ideal country in our imagination, even though our fantasy, as already said, is in danger of becoming over-reliant on English-speaking ecumenicalism.

It might perhaps be helpful to focus on the less polarized ethnic systems, such as the mixed societies in Latin America. Surely it is time to make a closer study of the mestizos, a rapidly expand- 
ing demographic category, rather than dismissing them as a residual group? Surely syncretism, that forms an element of so much religious experience, language, and material culture, should be celebrated rather than dismissed as a threat to traditions and cultural identity? Syncretism - or, generally speaking mixture - is what breathes new life into cultural expression. Up to now this has only been generally recognized in relation to popular music, even though that world also exhibits an almost inexorable tendency towards classification, which has institutionalized so-called world music as the syncretic music.

I concluded my commentary in the UN Report by stating that a positive contribution to the quest for less constricted interethnic relations could be made by paying tribute to the people who, in this era of forceful (ethnic) language, opt for compromise, negotiation and the middle course; who use weapons other than ethnicity to distinguish themselves or to inspire different peoples. Hence, it became obvious to me that Latin America deserved more attention from the side of ethnic studies. This has a direct impact on my own life. After completing my PhD at the University of Amsterdam I moved to Brazil first as a visiting scholar in 1992 and for good as a professor in 1996, when I became the coordinator of the Centre of Afro-Asian Studies (CEAA) in Rio de Janeiro. The years between 1996 and 2002 corresponded to the Presidency of Fernando Henrique Cardoso and his denunciation of racism as one of main Brazil national problems. Affirmative action became to be posited as a possible solution, though an inflamed debate which often used and abused the US civil right and affirmative action movement in search for symbolic support (BOURDIEU; WACQUANT, 1999). It was, however, only in 2002 with the advent of the Lula Presidency that affirmative action became a reality, albeit largely limited to the universities. Soon the question raised was what kind of multiculturalsim we want for Brazil.

\section{MULTICURALISM BRAZILIAN STYLE}

Although the themes of indigenous societies, race relations and above all slavery-based society and Afro-Brazilian religions played a central role in the foundation of the human sciences in Brazil, it is only in the years between 1996 and 2004 that the ethico-political questions raised by these areas of investigation gained visibility in society and, eventually, within scientific associations like 
the SBPC, ABA, Anpocs, Anped, Anphur and the SBS, as well as in academia more generally. Two main issues helped raise society's awareness concerning social inequalities among coloured groups in Brazil: the proposals for affirmative action in favour of black and indigenous entrants to university from state schools, and the need to implement Federal Law 10639 of 2003. The second case amounted to an initial attempt - generous but disorganized and decapitalized to create a Brazilian-style multiculturalism.

As said, affirmative action has been the form chosen by some nation states, especially after the Second World War, to try to quickly reverse the continuing legacy of extreme and deeply entrenched inequalities. India, Malaysia, Australia and South Africa, among others, have been experimenting with compensatory measures for castes, coloured groups, ethnic groups and other disadvantaged sections of the population, such as the visually impaired. In Latin America, in fact, experiments began to be pursued in this area only from the 1990s onwards, a period coinciding with the consolidation of re-democratization in the region. The phenomenon of multiculturalism emerged at the end of the 1970s as a pedagogical project, especially for schools and universities, but also in relation to public employment and associative life. This emergence took place in countries with a developed social welfare state and a public educational system that functions almost as a monopoly, a form of dealing with the cultural diversity brought above all by children of immigrants in schools, neighbourhoods and the work market. Countries with considerable experience in this area include Sweden, Canada, Australia, New Zealand, Holland and, to some extent, the United Kingdom and part of the United States. Nearer to the present, inspired by the idea that cultural difference may enrich rather than weaken the social life of a school, university or even company, multicultural experiments are being undertaken in countries with more recent experiences of immigration, such as those in southern Europe and finally Latin America. In the latter case, the experiments involved amplifying and revising school curricula, incorporating bodies of knowledge that had previously been left out, such as those related to indigenous or black identities. Ethno-education (Colombia, Ecuador, Nicaragua and to some extent Mexico) or education towards diversity (Brazil and Argentina) have been the terms characterizing this new, more plural phase in the world of education (SANSONE, 1998, 2003). 
It is worth adding that while the idea of multiculturalism was expanding in Latin America, it also entered into crisis, hit by criticisms from all sides, especially the conservative right, in countries that had begun this experiment. In Holland and the UK the insistence was once again on the need for (ethnic) minorities to 'integrate' with the behaviours of the majority - adopting tests to measure the degree of 'sociocultural integration' of immigrants in order for them to be granted a permanent visa. One of the victims of the 'war on terror' was multiculturalism itself, an attempt to conceive a more harmonious coexistence, transforming the double negative of difference/ distance into the double positive diversity/tolerance. Both in parts of Europe and in the United States, today there is a very strong government emphasis, backed by a much of public opinion, against the public support for other ethnic institutions, especially when Islamic in origin. Hence, we find countries like the UK, where the language of the State has incorporated the language or jargon of diversity, insofar as it is important to show a multiracial UK in its public manifestations, but where in reality the level of tolerance for multicultural or transcultural experiments in education is reduced to a minimum. (GILROY, 2006). The global context of multiculturalism is fairly complex, therefore: some countries began a short time ago, others have long-term experience; a new interest exists in some and crisis in others. On one hand we have a global icon: multiculturalism or, in the terminology more recently preferred by the United Nations, the World Bank, the Inter-American Development Bank and other international agencies, diversity - with promotion of the idea that the best development works with and in diversity. On the other hand, we have local or regional meanings of the terms multiculturalism and diversity - which cannot be the same in countries that began this experiment 40 years ago and in the last few years, or in countries with a legal traditional derived from Roman Law, with a universalist tendency, and those with a common law tradition, which tend to give more space to particularism.

In this sense it is very important to provide a detailed account of how multiculturalism has developed in Brazil, pointing to its high points and low points, as well as the new challenges that this phenomenon - or indeed, this movement, albeit disorganized - provides for Brazilian society. Until now it has primarily been in academia that efforts have been made to create some kind of multiculturalism. A good example is the case of ABA, which, though committed to 
anti-racism and intervention in favour of Brazil's indigenous population since its foundation in 1950, only set up its Commission of Ethnic and Race Relations (CRER) at its 2002 Congress, implementing a proposal developed by a still small group of anthropologists. At that time the debate surrounding 'quotas' for access to university was extremely intense, prompting ethical questions such as those concerning the use of photography as a tool for defining who is bla$\mathrm{ck}$ and therefore would have the right to benefit from quotas. CRER responded by indicating, in a note that provoked a polemical debate, the importance of self-declaration in identity processes and the dangers involved in using identifying photos at a moment when the aim is to transform negritude from a historical onus to a new bonus - in this case, to ensure a large number of black students are able to study at university. At the time, CRER still did not have an opinion concerning the so-called quota issue. Its members tended to be in favour, though some did not conceal a degree of scepticism. In the years of the Workers party (PT) governments (2002-2016) the context of our academic environment changed significantly, setting CRER new challenges ${ }^{1}$. I highlight three important changes in this direction:

The approval of affirmative action measures in a growing number of universities and their potential transformation into federal law by the National Congress.

The approval and gradual implementation of Federal Law 10639 of 2003, which obliges the incorporation of the themes of Afro-Brazilian history and cultures and African history and cultures at all levels of education.

The establishment of new targets for greater inclusion in Brazilian universities, such as the launch of a new national postgraduate plan by CAPES in 2005. This plan aimed to stimulate the increase in the number of doctoral students in Brazil, with the target of doubling this number within five years. One of the consequences was a greater willingness on the part of the CTC of CAPES to approve new graduate programs, implemented directly at doctoral level, including in new and multidisciplinary areas. For example, just in the area of human sciences at UFBA, between 2004 and 2006, another four postgraduate programs emerged, all including anthropologists among their academic staff, one program in particular - Graduate Program in Ethnic and African Studies - focusing closely on CRER's themes. The field of graduate studies is becoming a new frontier for measures for inclusion and even affirmative action ${ }^{2}$. The world of academic staff, the most difficult to change through measures like affirmative action or a multiculturalist discourse that 
values the diversity of the Brazilian population's social and ethnic-racial profiles, will undoubtedly be the next frontier. It is difficult to imagine a multicultural or transcultural university - closer to the real Brazil, including in terms of its research priorities - when there are so few black or indigenous university professors.

Clearly the increase in the number of black and indigenous students, especially in careers that have been traditionally more selective, unbalanced long-standing status quos. We can imagine the implications of the 'blackening' of the student intake in UFBA's law, odontology or medicine faculties, until very recently perhaps the whitest: will these students conform entirely to the culture of this university or will they, still conforming to a certain point, also demand new spaces, priorities and languages? It is also clear that this new presence in the graduate courses posed fresh challenges: the low-income levels of their families of origin mean that such students need specific grants and forms of support. In addition, in those institutions where 'quota' students have been entering already for some time, such as Catholic University (PUC) of Rio de Janeiro, which began offering grants to black and poor students on some courses almost a decade ago, demands have surfaced for the curricula to be modified, making them more multicultural - open to the reality of non-white and/or non-middle-class Brazilians.

For all these reasons, I believe that intellectuals engaged in anti-racism, within the more open university environment of the near future, will have to take the field of multiculturalism as their main source of action ${ }^{3}$. The need to make progress in creating a contextualized and anti-racist education raises new questions concerning the use of terms like black, Indian, Africa, quilombo and black culture, for example, in books that the Ministry of Education potentially distributes to thousands of schools. We need to act more vigilantly to avoid moving from forgetting to exaggeration. One example, in another area, of how sections of the population once virtually forgotten very quickly became the target of public policies without much substantiated debate is the field of healthcare and 'popular genetics' - where new processes of naturalizing differences are being created in rush of public initiatives for improving the health of ethno-racially defined groups, such as black and indigenous peoples. Other groups were being 'discovered' in this flourishing of initiatives, to a large extent associated with the Lula governments and their efforts to reverse injustices, for example, in relation to immigrants 
and migrants - with the elaboration of new statutes and laws that redefine the role of these populations. Perhaps Brazil can be seen today as a Pandora's Box in terms of the incorporation of public policies relating to specific demographic groups, based on valuing their cultural distinctiveness after centuries of forgetting. In Brazil, luckily, most of us believe that the different traditions of Afro-American, African and indigenous studies, and ethnic studies in general, must maintain a close dialogue among themselves. Perhaps this is one of the novelties of Brazil compared above all to the United States where the discussion on multiculturalism, when it involves the university, tends to be isolated within a single research tradition - leaving ethnic, African-American and African studies in a constant state of tension among themselves.

In indicating the new challenges that Brazil has been set to face from the moment that it proclaimed itself multicultural, I should now make my own position clear. I begin with an immediate declaration of faith, so to speak: I am in favour of affirmative action and what have been called quotas. I think that the appeal to the sacrosanct universalism as a motive to oppose these measures is baseless: universalism should not be a veil behind which certain groups manage to transform privileges into the rights of the few, but something to be put into practice. One of the reasons why I am critically in favour of quotas is that I am against those who are against. At root, as Paul Gilroy says, my universalism is strategic - inverting the priorities and the rhetoric of strategic essentialism, as defined by Gayatri Spivak.

In the movement that began with affirmative action and that should now lead to a multicultural intervention in the universities, I envisage three sorts of problems, though: the relation with measures of a social kind or, put otherwise, of class and income; the relation between identity politics and reparatory or redistributive measures; the type of content to be given to any transformation of the curricula towards multiculturalism - what is understood, for example, by Afro-Brazilian culture or indigenous culture?

a) The movement in favour of affirmative action and multicultura-
lism cannot serve as a way of avoiding the wider question of the ex-
treme and deeply entrenched inequalities that seem to characterize
the modernity of some countries, especially Brazil. Affirmative ac-
tion without combating inequalities means placing the emphasis in
the wrong place. Measures like quotas must be seen as something 
experimental, something to be continually evaluated, whose value is above all emblematic, and that needs to be complemented by other redistributive measures. In reality there can be no affirmative action without redistribution, just as we cannot speak of ethnic-cultural diversity disconnected from the question of ethnic-racial and social inequalities and discrimination. Affirmative action without a state social welfare project is little effective, save as a useful provocation. Diversity, in itself, does not represent a value, since it may signify all or nothing, though in the United States diversity ended up representing the Bush version of affirmative action. Affirmative action that does not presuppose any critical scrutiny of the mechanisms of inclusion and exclusion. Aside from defining the last two decades more than the relatively tolerant decades of the 1980s and 1990 s, proclaiming the importance of diversity means, much more simply, insisting on the importance of phenotypically varied people obtaining important high-profile positions, for example, among academic staff, or preaching the need to maintain cultural diversity, insisting more on the concept of unity - of a group - than on freedom, creativity and innovation. (APPIAH, 2005). In the Brazilian context, and in the Bahian case that I know best, I find troubling the attitude of those who argue that quotas can function alone, without measures and without a support infrastructure. As I experienced first-hand as head of Posafro, a quota without a grant is useless. Ethnic-racial measures cannot be considered unaccompanied by measures linked to class/income. We may even try to forget about class, but it will catch up with us sooner or later.

b) A second problem is related, in my view, to the rhetorical-ideological aspects of affirmative action. I am concerned by the theatrical dimension that the debate surrounding affirmative action took, especially during the presidency of Fernando Henrique Cardoso - with many more opinions for and against than real measures and policies. The debate was generally as abstract as it was acid. Now that quotas are a reality it is perhaps worth thinking in a more substantial form. I am sure that many of those colleagues against quotas can help think of other solutions and/or how to make them work - all of us agree that the quota holders deserve special attention and care - as well as think of a multicultural proposal that functions. I am convinced that a project for the effective incorporation of Federal Law 10639 within the academic environment, our major multicultural project for the time being, will function much better if considered more as an anti-racist educational project for tolerance than as an ethnic project, centred on the strengthening of sectoral identities through the (fossilized) culturalization of diversity ${ }^{4}$. We need to remain vigilant in relation to colour, which is why I do not propose a colour-blind posture, but between this colour blindness and a project centred on ethnogenesis, interme- 
diary solutions exist. The State must protect the citizen and create conditions for the identity process to occur without restrictions. We cannot privilege some identities, reifying them, or create measures based on narrow notions of identity. The aim should be to guarantee identities, not impose them. (APPIAH, 2005). I admit that my ethno-sceptic posture involves a contradiction: had there been no increase in people who declare themselves black or indigenous, political-ethnic categories, but only in those declaring themselves pretos and pardos, chromatic or phenotypical categories, we would not be speaking of affirmative action. I am, though, referring to more complex notions than the category of black or indigenous, which have already become absorbed into popular culture, as many studies show. I am thinking of the difficulty in putting these into practice, adapting notions like black or indigenous identity and black or indigenous culture to university teaching. This involves native terms that, transformed into analytic-descriptive categories, always end up with a restricted field of application - only some of those who consider themselves indigenous or black actually identify with some definition of black or indigenous identity or culture. This is why we should analyse what happened in the years 20022016 with the first time large scale incorporation of black activists in the federal government posts created to defend the interests of the Afro-Brazilian population. Not because it is not just to employ more black people, of course, but because this may end up exempting the machine of the State from making a more concerted effort against racism inside and outside its institutions. A similar type of co-option happened in relation to indigenous leaders - in a process that removed power from the village and emphasized translocal or regional associations. While it is wrong to idealize the village as a space of grassroots democracy, something that is in conflict, very often with the interests of the younger generations, neither is it right to forget that only some indigenous peoples, perhaps the most modern, recognize themselves in the associative life that the new opening of the Brazilian State both encourages and requires.

c) In relation to the type of content of our multiculturalism, what we shall have to teach in concrete terms - in discussing icons imbued with values and emotions like Africa, Africans, races, negritude, racism, being Indian and indigenous thought - I think it essential to emphasize plurality rather than insisting on speaking of culture and identity in the singular. The rebuilding of educational curricula must be aimed at showing the variety of cultural forms and identity processes, ensuring that this variety is seen to harbour both strength and creativity. According to the more modern notions of the human sciences, rather than being seen as entities, culture and identity should be seen and analyzed as projects and processes. This is why it is important that, instead of insisting on defining 
what, for example, Afro-Brazilian culture would be, by means of endless lists of items and traits that never succeed in incorporating the immense variety of the large Afro-Brazilian population, making static something that is always in movement, we develop methods that illustrate how different actors have produced culture, resistance and identity in diverse contexts. The real challenge is to apply these more modern notions of culture and identity at all levels of teaching, avoiding the practice that has left intellectual sophistication for the university, and made the primary and secondary school an environment where culture and identity, when approached, are treated in an overly traditional and rigid form contributing to a loss of interest in these themes among many students who, given a more dynamic teaching method, could certainly be interested. Indeed, teaching African histories and cultures, for example, can be extremely entertaining and stimulating, but also something fairly dull, as many students say, if pursued without the necessary sophistication.

As well as this multiplicity, it is worth insisting too on a greater attention to individuality and individuals. I do not think it opportune to always and only speak of Afro-Brazilians or indigenous peoples as populations, since this suggests that black and indigenous only function as collective entities and never also as individuals, with all the singularity that characterizes the human being. We need a language for teaching the themes of African and Afro-Brazilian histories and cultures capable of translating collective demands and experiences and individual trajectories and desires - whether the latter concern exemplary personalities (for example, illustrious figures like Milton Santos or Manuel Querino) or common black and indigenous people who have thus far remained nameless. This leads us into a real contradiction. At root the vocabulary of multiculturalism centres on the notion of majority versus minority, as well as community and ethnic identity, since it first emerged in societies where these practices were taken as a way of dealing with and incorporating into civil society those people defined as ethnic minorities, with the correlate assumption that they organize themselves and behave as a community, if not in residential terms than at least behaviourally. In the Brazilian context, where the black-mixed population in many regions comprises the majority or a 'large minority,' it is difficult to make use of the term community or minority, and the term identity has been used historically more to refer to (search for) a national identity rather than to specific groups. If the term identity is a relatively new term in the human sciences (GLEASON, 1983), it is even 
more so in the case of Brazilian academia. Perhaps we need to think of a terminology centred around the notion of exclusion-inclusion: we need to think of Brazil in a culturally and socially more inclusive form. Once again perhaps the strongest route would be that of an education in and towards tolerance, rather than an emphasis on the cultural diversity of part of the country's population. If we emphasize cultural diversity, we have to be careful how we define notions such as Afro-Brazilian culture or indigenous culture. Strong regional differences exist, as well as those between urban and rural, and between different social classes. For example, the iconography of negritude, present in the relatively few multicultural experiments developed to date, primarily reflects the reality of two unique cities, Salvador and Rio de Janeiro, and almost exclusively of the low-income social classes. By way of illustration, I can mention the results of my current research in the municipality of S. Francisco do Conde, just $80 \mathrm{~km}$ from Salvador. Interviewing a sample of 500 people, we found, for example, much more acceptance of the rezadeiras (faith healers) than of candomblé, and considerable interest in teaching the history of Africa in secondary school, even among those who said that they disliked candomblé. This shows a great variety of viewpoints on what 'being black' or 'Afro-Brazilian culture' amount to, a fact that needs to be taken into account when, with the best intentions, we simplify this universe in order to turn it into educational material for school texts or classes.

Due to the need to guarantee a plurality of expressions and not, once again, force people to identify themselves with constructions of what it is to be black or indigenous that are outside the reality of these people, I am convinced of the need to think of the identity process as far as possible as an affair of State. While an anti-racist education with cultural and religious tolerance is always emancipatory, something that can and must be supported by the State as a means to ensure the freedom of cultural, religious, sexual and even ethnic expression, one cannot say the same of a type of education centred on strengthening some type of ethnic identity. What, after all, is ethnic identity? It involves both an individual and collective feeling of belonging to a group defined or imagined to have a unique ancestral origin. It is almost always a political option, a choice. In terms of principles, I am in favour of granting (new) rights, including cultural rights, to all those groups and individuals with a history of ethnic-racial discrimination against them, but would prefer it to 
be these same groups and individuals who decide which cultural rights are to be claimed and how. My impression is that in most cases they will demand equality more than emphasize the fact of being (culturally) different. In this sense the State must remain attentive to these demands, but without predetermining them.

The question all this bears is how this is affecting the landscape of identity formation in Brazil and what will happen after the not-so-slow demise of the so-called identity wave, that period of resurgence of collective and sectorial identities based on ethnicity, gender and generation during which the term diversity ceased to mean an onus related to difference and inequality to become associated with egalitarian and redistributive policies. This wave took shape around 2002, in the first and most exciting stage of the first Lula government and, as a matter of fact, got in crisis with the consolidation of the Temer government. Such as in all radical processes there was a conservatory counter reaction the most extreme expressions of which can be found in the anti-identity idea set that gathers around the right-wing bully presidential candidate Bolsonaro and in the hateful climate with regards to minority identities that feeds into fake-news circulated by means of several websites commenting the most important political assassination of the last decade in Brazil, that of black activist Marielle Franco. If an important part of the population recognizes itself in the personality of Marielle and even celebrates it, many others loathe it exactly because they consider it too much identity-centred. Such new tension between (new) identity processes does not concern only Brazil, but concerns, even though in a less violent fashion, most countries in Latin America, as it was shown recently in Colombia where there was a strong opposition to the peace process and the amnesty proposed by the government, especially in the countryside and among the neo-Pentecostals. There the theme of the opposition was a conglomerate of slogans opposing whatever minority identity, such as homosexual, feminists and indios. The actual growth of religious intolerance towards any religious form of Afro-American or indigenous nature, in a region previously held as relatively tolerant in term of religion, can be understood, at least in part, as a reaction to the process of inclusion in the narrative of the State of such minority religious experience that had taken place in the previous two decades as part of new and growing multicultural policies taken by left-wing leaning governments which were in power in most of Latin America up to two or three years ago. 


\section{CONCLUSIONS}

As a matter of fact we need to discuss and debate the relationship between identity politics and (new) claims of citizenship and the State, because in our region we are facing a populist thorough rejection of the State and its codes or language that ends up affecting negatively and disempowers multicultural policies, which are identified by many, even in the lower classes, as part and parcel of the State machinery - the establishment - rather than the expression of the will of subaltern groups that have been historically discriminated against or as form to amend previous extreme injustice. In Brazil, such as in Trump's United States and other countries in the Americas one need to learn to cope, on the one hand, with the evidence that new formats of populism of the conservative sort are essentially against almost any multicultural experiment and, on the other hand, with the fact that a too close association between progressive politics and the promotion of new sectorial identities - even when they have been conceived of as measures in favour of groups of the population that have been historically discriminated against - is not alien to contradictions. It is, thus, not by accident that one of the best sold book in the social sciences in the post-Trump United States been meaningfully entitled After Identity Politics by Mark Lilla (Harper $\&$ Row). In closing, I believe that nowadays there is no way to conceive of more democratic and inclusive cultural politics from the part of the State without a thorough scrutiny of the opportunities and shortcomings of our new Latin American multiculturalism.

\section{REFERENCES}

APPIAH, A K. The ethics of identity. Princeton, NJ: Princeton University Press, 2005.

BELL, Daniel. Ethnicity and social change. In: GLAZER, N; MONYHAN, D. (eds.) Ethnicity. Theory and Experience. Cambridge Mass: Cambridge University Press, 1975. p. 141-174.

BOURDIEU, P.; WACQUANT, L. On the cunning of imperialist reasons. Theory, Culture and Society, v. 16, n. 1, p. 41-58,1999.

GILROY, P. Post-colonial melancholia. New York: Columbia University Press, 2006.

GLEASON, Philip. Identifying identity: a semantic history. The Journal of American History, v. 69, n. 4, p. 910-931, 1983. 
HANNERZ, U. Culture, cities and the world. Amsterdam: Centrum voor Grootstedelijk Onderzoek, 1992.

PEREZ DE CUELLAR, J. ed. 1996. Our creative diversity. report of the World Commission on Culture and Development. Paris: UNESCO, 1996. Available in:<http://unesdoc.unesco.org/ images/0010/001055/105586e.pdf >

SANSONE, L. Multiculturalismo, Estado e modernidade - as nuanças em alguns países europeus e o debate no Brasil. Dados, v. 46, n. 3, p. 535-556, 2003.

. Racismo sem Etnicidade. Políticas Públicas e Discriminação Racial em Perspectiva Comparada. Dados, v. 41, n. 4, p. 20-40, 1998.

TAYLOR, Charles. Multiculturalism: examining the politics of recognition. Princeton, New Jersey: Princeton University Press, 1994.

TURNER, B. Religion and global politics. Religion and Social Theory, London: Heinemann, 1983.

UNITED STATES CENSUS BUREAU. Race and Ethnicity. [S. 1.], jan. 2017. Available in: $<$ https://www.census.gov/mso/www/training/ pdf/race-ethnicityonepager.pdf $>$.

VERMEULEN, H. De bruikbaarheid van het cultuurconcept. Antropologische Verkenningen, [S. 1.], v. 13, n. 2, p. 34-40, 1994.

WALLERSTEIN, I. Culture is the Ideological Battleground of the Modern World-System. In: FEATHERSTONE, M. (Ed.). Global Culture. London: Sage, 1990. p. 31-56.

\section{Notas:}

1 As from 2016 the context has changed again and in many ways things have moved backwards.

2 Quotas in the process of admission to graduate programs have started to be enforced in several public universities, including the Federal University of Bahia where I have been working since 2017.

3 See José Jorge de Carvalho's, from the University of Brasília, pioneering work over the last decade. See more in <http://www.inctinclusao.com.br/>.

4 This is what we are attempting in the Ideas Factory Program and Posafro. 
